\title{
sciendo
}

WSB Journal of Business and Finance

Year 2019, Vol. 53, No. 1

eISSN 2657-4950

\section{Motivation and Action Control in a Saving Lifestyle}

\author{
Konrad Hryniewicz ${ }^{1_{a}}$ \\ aWPS University of Social Sciences and Humanities, Warsaw, Poland \\ (C) 2019 Konrad Hryniewicz. This is an open access article distributed under the Creative Commons Attribution- \\ NonCommercial-NoDerivs license (http://creativecommons.org/licenses/by-nc-nd/3.0/
}

DOI 10.2478/WSBJBF-2019-0014

\begin{abstract}
The article presents three studies about saving money described as a routine behaviour and a way of life. The results underline the role of perceived risk, benefits and self-efficacy as motivational variables affecting savings and the meaning of strategies in action control that facilitate the intention to save and maintenance of saving behaviour. The mechanisms of control tested were action planning and coping with problems, monitoring of saving behaviour, maintenance of self-efficacy and its recovery after setbacks. The first study, using structural equation modelling, presents the meaning of motivational variables in the prediction of intentions and the mediating role of action control functions in explaining the relationship between intention and savings $(N=227)$. The second study in the experimental arrangement confirms the beneficial influence of the same variables on financial decisions in unforeseen savings opportunities $(N=460)$. The final study shows the beneficial results of a cognitive training session, which was focused on inducing motivation and raising the level of action control in the area of saving. These studies explain the motivation to save and maintenance of saving behaviours, which lead to consistent and sustainable saving actions.
\end{abstract}

Keywords: saving; behaviour maintenance; planning; action control; self-efficacy; behavioural change

\section{$1 \quad$ Introduction}

Behaviours related to a lower ability to save as manifested in unplanned spending, habitually succumbing to temptations and lack of control over finances are hard to change. Most social cognitive theories assume that the intention to engage in the desired behaviour is the best predictor of a behaviour (Ajzen 1985; Prochaska, Wright, and Velicer 2008; Steinmetz, Knappstein, Ajzen, Schmidt and Kabst 2016). These theories are very good at explaining the variance in intentions, but they are not capable of predicting behaviour. They do not take into account the fact that people often behave contrary to their intentions. The reasons for acting this way are unforeseen obstacles, indulging in temptation, procrastination, lack of energy and also lack of mental ability to act. Khul indicates that realisation of intention must be supported by a behavioural system of action control (Kuhl 2000). Without its activation through positive affect regulation, the will to act is only represented in memory, but not in real behaviour (Goschke and Kuhl 1993; Kuhl and Helle 1986; Zeigarnik 1927). He describes this situation as a state orientation. Transition from this state to action state and the execution of intention must be supported by cognition mechanisms, which modulate the affect and thus facilitate initiation and control over behaviour. The concept of control has particular importance in the area of saving, which is taken up for discussion in this paper. Several studies support the hypothesis that action control plays a crucial role in the context of consumer decisions and financial actions (Baumeister 2002; O'Guinn and Faber 1989; Rook and Gardner 1993; Rook and Fisher 1995; Faber and Vohs 2011; Sotiropoulos and d'Astous 2013), and a low level of savings leads to adverse economic, health, social and legal consequences (Drever et al. 2015; Jian, Chen, and Chen 2014; Taylor, Jenkins, and Sacker

\footnotetext{
${ }^{1}$ Metodolog.pl@gmail.com
} 
2011; von Stumm, Fenton O'Creevy, and Furnham 2013; Worthy, Jonkman, and Blinn-Pike 2010). Therefore, it is obvious that action control is one of the clear determinants of financial behaviours and their aftereffects. Therefore, from the perspective of explaining the struggle to save, it may be assumed that money can effectively be put aside for saving by treating saving as an area in which motivations and action control are elements of a financially healthy lifestyle (Dholakia, Tam, Yoon and Wong 2016). This work seeks to clarify the role of behavioural control in saving, as well as to verify motivational variables that trigger the intentions that manifest in the action of putting the money aside for saving. Saving is defined as a personal orientation towards a lifestyle in which a beneficial savings behaviour is maintained. This lifestyle manifests itself in habitual, routine activities and occasional striving to put money aside, and also in efforts towards maintaining financial well-being (Bagozzi and Warshaw 1990; Dholakia et al. 2016). Due to the personal and social benefits of behaviours that result in financial well-being, they can be equated with strengthening and maintaining a physically healthy lifestyle (Leventhal, Rabin, Leventhal and Burns 2001; Ouellette and Wood 1998; Schwarzer 2008).

In this research, three studies were conducted. Psychological mechanisms leading to saving were investigated in two studies. The third applied these mechanisms in a financial coaching practice (Delgadillo 2014). The first study, using structural equation modelling, confirms the predictions in the context of the role motivational variables play in determining saving intentions and also verifies the role of the mechanisms of action control related to saving. The second shows how situational activation of motivational variables, intention and features of action control affect decisions related to saving in the event of an unexpected opportunity to save. The third shows the results of a four-hour cognitive training session focused on behaviour change leading to saving. The conclusion of this paper covers the proposals for further studies, guidelines for practitioners engaged in financial advice and decisionmakers who design interventions directed at behaviour change as well as limitations of the performed research activities.

\section{Motivation, intention and action control in saving}

A saving lifestyle is considered to have two stages with distinctive patterns of behaviour. The first is the process of motivation, which evokes an intuition towards the desired behaviour (Fishbein and Ajzen 1975), and second is a volitional step, which supports the realisation of the intention and control over the behaviour in line with the intention in question (Bandura and Adams 1977; Baumeister 2002; Gollwitzer 1999; Kuhl 2000; Marlatt, Baer and Quiglet 1995; Marlatt 2002). A concrete pattern of variables (fig. 1) that perform a crucial function in determining behaviour and its maintenance emerge in these steps. During the motivational phase, the intention to save is first created. The first motivational variable, which affects the will to action-taking, is the perception of risks related to the lack of savings and the resulting feeling of threat. It activates behaviours that aim at controlling threat by formulating operation plans and the attempts to change one's personal situation (Leventhal, Safer and Panagis 1983; Renner 2003; Schwarzer 2008). The second motivator is noticing the importance of benefits resulting from savings (Vroom 1964). A positive valence of having savings as well as self-efficacy concerning the implementation of appropriate actions leading to retrenchment are baseline factors for formulating attempts to acquire new and difficult behaviours (Bandura 1977; Vroom 1964). The positive result of mentally calculating the balance between the multiplicity of perceived risks and the benefits related to depositing money are the determinants of the saving-oriented mindset. Along with self-efficacy in one's behaviour directed towards saving, it becomes the groundwork for formulating intentions to action-taking (Fishbein and Ajzen 1975; Schwarzer 2008).

After a person develops an intention, he or she must turn it into a detailed vision of how to perform specific actions and what to do to maintain them. This is not achieved by a single act of will determined by intention. This requires cognitive skills and self-control strategies. This work delineates five volitional variables that denote action control functions. The first three are specific beliefs about self-efficacy (Bandura 1977; Marlatt, Baer and Quiglet 1995). Considering the classification of self-efficacy of Marlat, Bear and Quiglet, a distinction is made between (1) action self-efficacy, (2) maintenance self-efficacy and (3) recovery self-efficacy. The first refers to the motivation step, already mentioned, in which the person does not do anything yet, but develops a willingness to perform a given behaviour. The second refers to optimistic beliefs about the personal ability to deal with barriers during the behaviour maintenance period. New financial actions may turn out to be more difficult to maintain than expected. However, a person with a high level of performance will react more confidently, design better strategies, make efforts and display prolonged persistence in overcoming the obstacles. The third is the recovery of self-efficacy after setbacks and the return to the desired behaviours. It concerns trust in one's own competence in regaining control over behaviour and reducing harm after a failure (Marlatt 2002). A person with a high level of this feeling will try to attribute relapses of undesirable behaviours to risky and external situations and will look for ways to regain control in the pursuit of saving. This distinction has proven useful in different domains of behavioural change (Marlatt et al. 1995). Action self-efficacy predicts the intentions to undertake the desired behaviour (Fishbein and Ajzen 1975), while maintaining self-efficacy and recovery of self-efficacy seek to stabilise the behaviours already being practiced. 
Two consecutive mechanisms that control behaviour are mental simulations that identify the cues to action and transform the formulated intention to behaviour. The first of them is the implementation of intention (Gollwitzer 1999). It refers to the formulation plans for "when", "where" and "how" to perform a given behaviour. Such an action is something more than an extension of a simple intention, because it allows the creation in advance of a cognitive representation of the situation in which one can perform a previously planned sequence of behaviours. When such situational cues are encountered, an action specified in this way can be triggered automatically. Meta-analysis has proved that formulating plans in this manner has a significant impact on achieving consumer goals (Gollwitzer and Sheeran 2006). The second mechanism is planning for coping, which involves predicting barriers and preparing alternative behaviours to overcome those barriers (Scholz, Sniehotta, Burkert and Schwarzer 2007; Sniehotta, Scholz and Schwarzer 2005). If such a situation arises, people can imagine scenarios that make it difficult for them to perform their intended behaviour and develop plans to deal with them. The last discussed element of behaviour control is monitoring (Baumeister 2002). This mechanism allows individuals to track their own divergent and convergent activities with the goal of saving and thus support the intention. When people follow the process of saving, unwanted purchases as well as loss of money in an unconsidered way are less likely. It is especially important in the maintenance process because vigilant observation of one's own actions, which is embedded in a dynamic environment, allows individuals to see new possibilities, situations and ways of behaving, and then use them to correct plans or construct new ones.

All of the mentioned variables have been conceptualised as key elements of behaviour control that mediate between intention and the striving to save money. This was done due to the fact that despite the differences between these mechanisms, they are concerned with a coherent universe of functions that control the intentional behaviour (Kuhl 1984; Kuhl 2000). These mechanisms prevent the emergence of the degenerated intention, a phenomenon that Kuhl calls cognitive representation in which one or more elements of intentions are poorly defined, activated or not specified at all. This causes state orientation and limits the possibility of implementing actions (Kuhl 1984). In the following sections of the article, there are empirical data from three studies verifying the abovementioned mechanisms related to the pursuit of saving. At the same time, they confirm the accuracy of predictions resulting from the tested variables in the context of motivating an individual to a saving lifestyle as well as its maintenance.

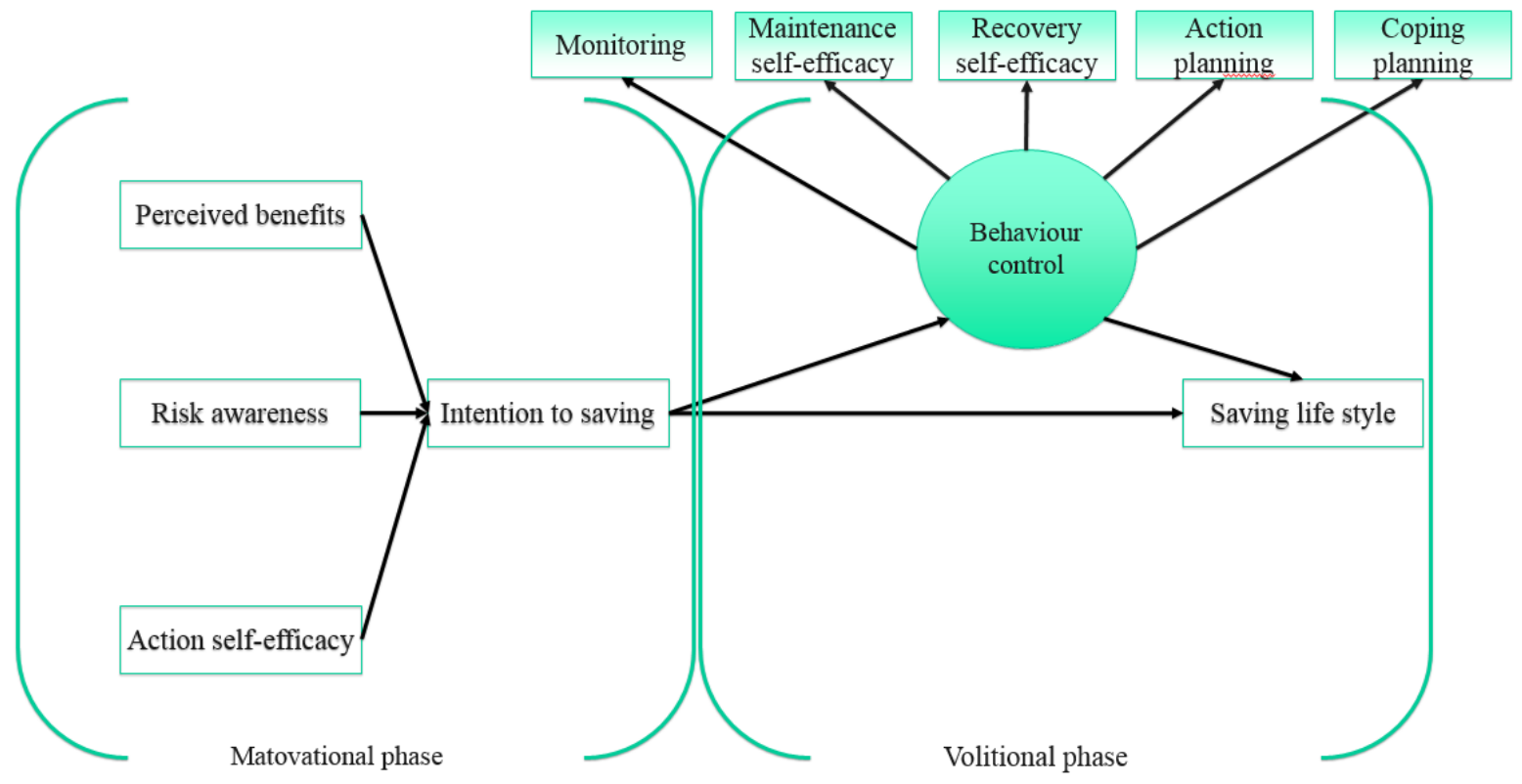

Fig. 1. Motivational and volitional phase in striving to saving.

The overall objective of the study was to verify the predictions resulting from theoretical premises concerning the casual mechanism explaining the saving lifestyle. For this reason, the first goal of the analysis was to obtain information about the factorial validation of the questionnaire measurements of the tested variables, and 
the second the verification of the accuracy of predictions in the context of the functions of the influences of distinctive motivational variables, intentions and behaviour control. Two hypotheses were formulated:

H1: Questionnaire measurements of motivational variables, intentions and behaviour control are reliable and factor-specific.

H2: Motivational variables directly influence the intention to save, and its impact on a saving lifestyle is mediated by mechanisms of behaviour control.

Method. The study was conducted by using an Internet version of the questionnaire, which was displayed to the students of the Medical University of Gdańsk using Facebook ads. During its lifetime, 598 people clicked on the survey. While 248 completed it in the first stage, 227 people answered the questions in the second experiment after 30 days. An incentive to complete the survey was the possibility of winning one of the three prizes (a telephone, a small loudspeaker and headphones). In the research, there was a total of 227 respondents ( $80 \%$ female) aged $M=24.21 ; S D=6.57$ (range 19-53). In the first step of the study, motivational variables and behavioural controls (except monitoring) were measured as well as demographic and contact variables to complete the study in the second step. The theoretical significance of the variables was operationalised using the content of the test items in the survey (for a full set, see appendix A). In the first stage of the study, the following motivation variables were tested. The sample test items are shown in brackets: Risk awareness (e.g. compared to the average person of my sex and my age, the chances of me suffering from lack of money are high); perceived benefits (e.g. If I save, then I'm calmer); action self-efficacy (e.g. Nothing can stop me from saving); intention (e.g. I'm going to save money); and volitional variables, such as action planning (e.g. I know in which situations I will be able to save); maintenance of self-efficacy (e.g. I'm sure that I can resist the temptation to make unplanned purchases and save even when I'm on unexpected shopping trips with friends); regaining self-efficacy (e.g. I'm sure I'll return to saving even when I fall back into unplanned spending for some time); and planning for coping (e.g. I have a detailed plan on how to avoid situations in which saving is difficult or impossible). In the second stage of the study, after 30 days, an email and SMS were sent to the participants with a link to the monitoring questions (e.g. I remember when and where I saved something), and the represented level of saving lifestyle (I have high savings; I manage to create a financial reserve; My life is so organised that I live normally and save; I create savings to deal with future expenses; I conscientiously try to save money). Responses to test items were measured on a four-level scale: "Not true", "Partially untrue", "Partially true" and "True". Information about the number of test items per measurement of each variable, the level of reliability and correlation is presented in table 2 .

Results. The analysis was carried out by the author. In order to verify hypothesis no. 1, the confirmatory factor analysis in the IBM AMOS 23 program was done. It was predicted that the theoretical constructs specified in the form of latent variables will be observed in the variability of the results obtained from specific items of the questionnaire. Preliminary analysis showed that the test items regarding the measurement of intention (I intend to reduce the number unplanned purchases) lowered the reliability of the indicator; it was therefore removed from the analysis. Analysis of the results of the confirmatory factor analysis based on the ML estimation method showed a very satisfactory fit of the predicted structure to the collected data $(C M I N / D F=1.47, S R M R=0.047, G F I=0.81$, $C F I=0.90, T L I=0.89, R M S E A=0.05 ; 95 \% \mathrm{Ci}(0.04-0.05))$. Latent variables influenced the answers obtained in the survey in the range of $\beta=0.24-0.90\left(R^{2}=0.06-0.81\right)$, and were also reliable measurements $(\alpha=0.53-0.88)$. The results of the analysis are presented in table 1 . Table 2 shows the correlations between variables used in building the model. Using these variables, hypothesis 2 was verified. For this purpose, a structural equation modelling using ADF method was employed in order to assess the fit of the theoretical model to empirical data. Analysis of the structural model in which results are shown in figure 2 showed a satisfactory fit to the model $(C M I N / D F=2.00$, $S R M R=0.05, G F I=0.94, C F I=0.83, T L I=0.75, R M S E A=0.07 ; 90 \% \mathrm{Ci}(0.04-0.09))$. It showed a significant impact on the action self-efficacy and perceived benefits on the intention to save. Intention, on the other hand, significantly affected the level of behavioural control variables (the latent trait was a significant and valid source of their variability; results of confirmatory factor analysis for the dimension of behavioural control (CMIN/DF=0.99, $S R M R=0.04, G F I=0.99, C F I=1, T L I=1, R M S E A=0.00 ; 90 \% \mathrm{Ci}(0.00-0.09))$, and these, in turn, impacted saving. The action self-efficacy also had a significant impact on the level of variable behavioural control and the level of saving. However, a comparative analysis of $\beta$ path factors showed that the saving lifestyle was significantly more strongly explained by behaviour control $(\beta=0,45, p<.001)$ than by the action self-efficacy $(\beta=0,29, p<.001$; this difference was statistically significant; $Z=2.08$ ). As expected, behaviour control was mediated by the effect of intention on saving. The analysis of mediation, understood in accordance with Baron and Kenny's line of thought (1986), showed that these variables completely mediated the relationship between intention and saving $(\beta=0,13$, $p<.05 ; 95 \% \mathrm{Ci}(0.02-0.37)$. Further analysis of mediation showed that the intention together with the variables of behaviour control significantly mediated between the action self-efficacy and saving $(\beta=0.32, p<.01 ; 95 \% \mathrm{Ci}$ $(0.13-0.62)$. This effect was not total, because the action self-efficacy was still a significant predictor of saving $(\beta=0.29, p<.001)$.

Summary. The analysis performed in study 1 confirmed hypotheses 1 and 2 . The structure of measurements was verified as reliable and factorial valid. The structural model showed that the savings were partly explained by the variance between variables specified therein $\left(R^{2}=0.49\right)$. It was shown that the action self-efficacy and benefits of 
having savings influenced the willingness to save. There was no significant role of perceived risk, which is explained in the summary. The statistical model confirmed the reasons for the impact of motivation variables on intention to save, as well as on the variable behavioural controls that combine intention and savings. Analysis of the mediation effect showed that behavioural control completely reduced the direct impact of the intent to save. In addition, the model expanded the conclusions about action self-efficacy and showed that it had a direct impact on both the level of intention, behaviour control and saving lifestyle. Apparently, this variable is important in the broad spectrum of the process of motivation, action and its maintenance (Bandura 1997, Marlatt, Baer and Quiglet 1995).

Table 1. The results of confirmatory factor analysis.

\begin{tabular}{|c|c|c|c|c|c|c|}
\hline Items & $\begin{array}{c}\text { Latent } \\
\text { variable }\end{array}$ & $B$ & S.E. & $\beta$ & $R^{2}$ & $Z$ \\
\hline Intention to saving 1 & \multirow{3}{*}{$\begin{array}{l}\text { Intention to } \\
\text { saving }\end{array}$} & 1 & & 0,68 & 0,46 & \\
\hline Intention to saving 3 & & 1,54 & 0,16 & 0,79 & 0,63 & $9,44 * * *$ \\
\hline Intention to saving 4 & & 1,41 & 0,15 & 0,76 & 0,58 & $9,25 * * *$ \\
\hline Risk awareness 1 & \multirow{3}{*}{$\begin{array}{c}\text { Risk } \\
\text { awareness }\end{array}$} & 1 & & 0,67 & 0,45 & \\
\hline Risk awareness 2 & & 0,88 & 0,1 & 0,73 & 0,54 & $9,10 * * *$ \\
\hline Risk awareness 3 & & 1,25 & 0,14 & 0,87 & 0,76 & $9,21 * * *$ \\
\hline Perceived benefits 1 & \multirow{6}{*}{$\begin{array}{l}\text { Perceived } \\
\text { benefits }\end{array}$} & 1 & & 0,36 & 0,13 & \\
\hline Perceived benefits 2 & & 1,07 & 0,42 & 0,24 & 0,06 & $2,58^{*}$ \\
\hline Perceived benefits 3 & & 1,51 & 0,34 & 0,53 & 0,28 & $4,40 * * *$ \\
\hline Perceived benefits 4 & & 1,07 & 0,34 & 0,33 & 0,11 & $3,15^{* * *}$ \\
\hline Perceived benefits 5 & & 1,98 & 0,52 & 0,53 & 0,28 & $3,83 * * *$ \\
\hline Perceived benefits 6 & & 1,69 & 0,44 & 0,55 & 0,31 & $3,81 * * *$ \\
\hline Action self-efficacy 1 & \multirow{4}{*}{$\begin{array}{l}\text { Action self- } \\
\text { efficacy }\end{array}$} & 1 & & 0,7 & 0,5 & \\
\hline Action self-efficacy 2 & & 0,89 & 0,08 & 0,68 & 0,46 & $11,88^{* * *}$ \\
\hline Action self-efficacy 3 & & 1,24 & 0,11 & 0,9 & 0,81 & $11,85^{* * *}$ \\
\hline Action self-efficacy 4 & & 1,14 & 0,1 & 0,8 & 0,63 & $10,95^{* * *}$ \\
\hline Maintenance self-efficacy 1 & \multirow{5}{*}{$\begin{array}{l}\text { Maintenance } \\
\text { self-efficacy }\end{array}$} & 1 & & 0,72 & 0,51 & \\
\hline Maintenance self-efficacy 2 & & 1 & 0,1 & 0,73 & 0,53 & $9,65 * * *$ \\
\hline Maintenance self-efficacy 3 & & 1 & 0,1 & 0,72 & 0,52 & $9,56 * * *$ \\
\hline Maintenance self-efficacy 4 & & 0,84 & 0,1 & 0,66 & 0,44 & $8,87^{* * *}$ \\
\hline Maintenance self-efficacy 5 & & 0,43 & 0,12 & 0,28 & 0,08 & $3,78^{* * *}$ \\
\hline Recovery self-efficacy 1 & \multirow{5}{*}{$\begin{array}{l}\text { Recovery } \\
\text { self-efficacy }\end{array}$} & 1 & & 0,7 & 0,5 & \\
\hline Recovery self-efficacy 2 & & 1,09 & 0,1 & 0,8 & 0,64 & $10,47 * * *$ \\
\hline Recovery self-efficacy 3 & & 1,2 & 0,12 & 0,79 & 0,62 & $10,41^{* * *}$ \\
\hline Recovery self-efficacy 4 & & 0,89 & 0,13 & 0,51 & 0,26 & $7,01 * * *$ \\
\hline Recovery self-efficacy 5 & & 1 & 0,12 & 0,59 & 0,35 & $8,01 * * *$ \\
\hline Action planning 1 & \multirow{6}{*}{$\begin{array}{c}\text { Action } \\
\text { planning }\end{array}$} & 1 & & 0,6 & 0,36 & \\
\hline Action planning 2 & & 1,36 & 0,14 & 0,79 & 0,63 & $9,88 * * *$ \\
\hline Action planning 3 & & 0,94 & 0,11 & 0,63 & 0,4 & $8,91 * * *$ \\
\hline Action planning 4 & & 1,21 & 0,15 & 0,79 & 0,62 & $8,35 * * *$ \\
\hline Action planning 5 & & 1,39 & 0,15 & 0,83 & 0,68 & $9,01 * * *$ \\
\hline Action planning 6 & & 1,26 & 0,15 & 0,73 & 0,53 & $8,41 * * *$ \\
\hline Coping planning 1 & \multirow{3}{*}{$\begin{array}{l}\text { Coping } \\
\text { planning }\end{array}$} & 1 & & 0,48 & 0,23 & \\
\hline Coping planning 2 & & 1,16 & 0,17 & 0,57 & 0,32 & $6,79 * * *$ \\
\hline Coping planning 3 & & 1,42 & 0,21 & 0,78 & 0,61 & $6,75^{* * *}$ \\
\hline
\end{tabular}




\begin{tabular}{|c|c|c|c|c|c|c|}
\hline Coping planning 4 & & 1,29 & 0,2 & 0,71 & 0,51 & $6,51^{* * *}$ \\
\hline Coping planning 5 & & 1,39 & 0,22 & 0,69 & 0,48 & $6,42 * * *$ \\
\hline Monitoring 1 & \multirow{7}{*}{ Monitoring } & 1 & & 0,74 & 0,55 & \\
\hline Monitoring 2 & & 0,66 & 0,08 & 0,6 & 0,36 & $8,42 * * *$ \\
\hline Monitoring 3 & & 0,77 & 0,09 & 0,62 & 0,38 & $8,75^{* * *}$ \\
\hline Monitoring 4 & & 0,76 & 0,08 & 0,69 & 0,47 & $9,71 * * *$ \\
\hline Monitoring 5 & & 0,98 & 0,09 & 0,79 & 0,62 & $11,06 * * *$ \\
\hline Monitoring 6 & & 0,86 & 0,09 & 0,69 & 0,48 & $9,80^{* * *}$ \\
\hline Monitoring 7 & & 0,45 & 0,09 & 0,36 & 0,13 & $5,09^{* * *}$ \\
\hline Saving life style 1 & \multirow{5}{*}{$\begin{array}{l}\text { Saving life } \\
\text { style }\end{array}$} & 1 & & 0,65 & 0,42 & $10,58^{* * *}$ \\
\hline Saving life style 2 & & 1,25 & 0,12 & 0,87 & 0,76 & $10,05 * * *$ \\
\hline Saving life style 3 & & 1,15 & 0,12 & 0,81 & 0,65 & $9,47 * * *$ \\
\hline Saving life style 4 & & 1,04 & 0,11 & 0,75 & 0,55 & $9,47 * * *$ \\
\hline Saving life style 5 & & 1,08 & 0,11 & 0,76 & 0,58 & $9,65^{* * *}$ \\
\hline
\end{tabular}

$\mathrm{CMIN} / \mathrm{DF}=1,47, \mathrm{SRMR}=0,047, \mathrm{GFI}-0,81, \mathrm{CFI}=0,90, \mathrm{TLI}=0,89, \mathrm{RMSEA}=0,04595 \% \mathrm{Ci}(0,040-0,051){ }^{*} \mathrm{p}<.05,{ }^{* *} \mathrm{p}<.01,{ }^{* * *} \mathrm{p}<.001$

Table 2. Information about variables which build the structural model.

\begin{tabular}{|c|c|c|c|c|c|c|c|c|c|c|c|c|c|}
\hline & $M$ & $S D$ & Item & $\alpha$ & 1 & 2 & 3 & 4 & 5 & 6 & 7 & 8 & 9 \\
\hline Intention to saving (1) & 3,32 & 0,7 & 3 & 0,78 & & & & & & & & & \\
\hline Risk awareness (2) & 1,82 & 0,78 & 3 & 0,79 & $-0,11$ & & & & & & & & \\
\hline Perceived benefits (3) & 3,47 & 0,48 & 6 & 0,53 &, $50^{* * *}$ & $-0,05$ & & & & & & & \\
\hline Maintenance self-efficacy (4) & 3,00 & 0,71 & 5 & 0,77 &, $25^{* * *}$ & $21^{-}$ &, $25^{* * *}$ & & & & & & \\
\hline Monitoring (5) & 2,68 & 0,51 & 7 & 0,83 &, $24^{* * *}$ & 0,02 &, $18^{* * *}$ & 0,09 & & & & & \\
\hline Coping planning (6) & 2,71 & 0,73 & 5 & 0,79 &, $18^{* * *}$ & $-0,02$ &, $18^{* * *}$ &, $51^{* * *}$ &, $23^{* * * *}$ & & & & \\
\hline Recovery self-efficacy (7) & 3,25 & 0,67 & 5 & 0,81 &, $46^{* * *}$ & $-0,13$ &, $33^{* * *}$ &, $33^{* * *}$ &, $15^{*}$ &, $33^{* * *}$ & & & \\
\hline Action planning (8) & 3,22 & 0,65 & 6 & 0,88 &, $27^{* * * *}$ &, $23^{-}$ &, $22^{* * *}$ &, $53^{* * *}$ & 0,13 &, $57^{* * *}$ &, $42^{* * *}$ & & \\
\hline Action self-efficacy (9) & 2,54 & 0,84 & 4 & 0,86 &, $35^{* * *}$ &, $21^{-* * *}$ &, $34^{* * *}$ &, $44^{* * * *}$ &, $18^{* * *}$ &, $42^{* * * *}$ &, $46^{* * *}$ &, $57^{* * * *}$ & \\
\hline \multirow[t]{2}{*}{ Savings (10) } & 2,86 & 0,75 & 5 & 0,87 &, $43^{* * *}$ &, $27^{* * * *}$ &, $34^{* * *}$ &, $36^{* * *}$ &, $22^{* * *}$ &, $34^{* * *}$ &, $48^{* * *}$ &, $46^{* * *}$ &, $64^{* * *}$ \\
\hline & & & & & & & & & $\dagger<0,10$ & $* \mathrm{p}<<$. & ${ }^{* *} \mathrm{p}<$ & $01, *$ & $<.001$ \\
\hline
\end{tabular}




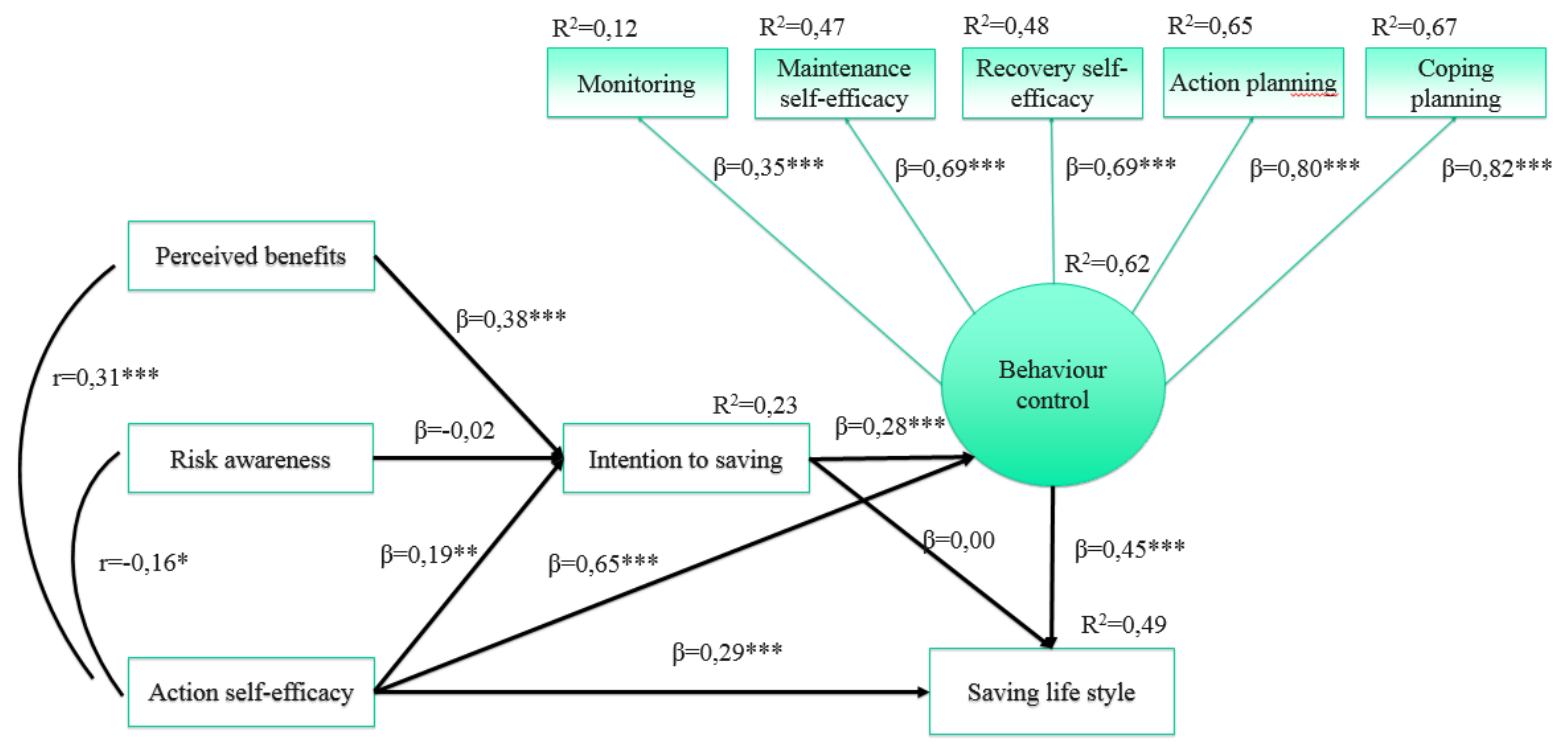

$\mathrm{CMIN} / \mathrm{DF}=2,00, \mathrm{SRMR}=0,046, \mathrm{GFI}=0,94, \mathrm{CFI}=0,83, \mathrm{TLI}=0,75, \mathrm{RMSEA}=0,07$

$\dagger<0,10 * \mathrm{p}<0,05, * * \mathrm{p}<0,01, * * * \mathrm{p}<0,001$

Fig. 2. The structural model of the expected direction of the impact of the motivational variables, intention, and behavioural control on the

level of the saving lifestyle.

\section{$4 \quad$ Study 2}

Study 2 was intended to show the impact of motivation variables, intentions and behaviour control on the level of saving that was achieved. Participants had a structured way to express their beliefs and describe the behaviours associated with saving money, and then decide how much they would save out of PLN100 (\$29) if they found it or got it. It was hypothesised that the activation of motivators, intentions and behaviour control elements will affect the level of savings. It was also anticipated that self-efficacy as the ability to cope with difficulties and the main cognitive mediator in the process of initiating and maintaining behaviour (Bandura 1977) will be a mechanism operating between motivation, intention and control variables and the decision to allocate money for savings. On this basis, the following hypotheses were formulated:

H3: Motivators, intention to save and variable behaviour control have an impact on the decision regarding the amount of money set aside as savings.

H4: Self-efficacy is a mechanism explaining the influence of intention and control behaviour on the decision regarding the amount of money set aside as savings.

Method: The survey was conducted via the Internet version of a survey on Facebook. The advertisement was displayed to the students of University of Lodz using Facebook ads.

The incentive to complete the survey was the possibility of winning one of the three prizes (a mobile phone, a loudspeaker and headphones). A total of 460 respondents ( $72 \%$ women) aged $M=22.89, S D=4.56$ (range 18-55) took part in 10 different versions of the survey. It was found that 2217 people clicked on the research link and 472 filled it to the end. Due to superficial and repetitive responses, 12 observations were removed from the study. Participants took part in 9 experimental conditions and one control.

The dependent variable that was measured in the study was a saving decision. The respondents were to imagine what they would do if they found or received PLN100 (\$29) and decide how much of this amount they would save (Garbinsky 2013, study 1). Motivational factors, intentions and variables of behaviour control were activated by asking respondents in various conditions to describe their attitudes, perceptions and behaviours related to saving. Assuming the conditions of risk and benefit perception, the respondents had to write down five negative consequences and benefits that would result from savings. In the condition of eliciting intentions, the respondents had to write out three saving goals, how much money they have to set aside for each of them and specify the time of their realisation. In maintenance of self-efficacy condition, the respondents had to write about three barriers to saving, and what they can do to overcome them and at the same time keep their well-being. In the monitoring group, the respondents were to write three ideas: they would learn that they would save, in what situations of everyday life they could save, what they could do themselves to save, and how they would assess whether they are saving well. In the case of planning for coping, the participants had to write three problems that can occur as a barrier to saving money, what they can do to prevent these problems and how to overcome them when they occur. 
In the planning condition, the respondents had to write three situations in which they can save, how they can do it and when and where. The action self-efficacy was triggered by writing out three problems that interfere with building savings and asking them to describe ways to overcome them. In the context of recovery, respondents were asked to write three situations that could cause them not to stop or completely stop the process, and what they can do to return to saving. In the control condition, the respondents were asked to describe the movements they perform when tying their shoes. Then, in all conditions, the respondents gave information about demographics and responded to a three-point scale: (1) It fails to describe me; (2) It describes me a little; and (3) It describes me completely. They were asked if the statements that measure self-efficacy in saving match their behaviour: (1) At the moment, I feel capable of working effectively towards my long-term savings goals; (2) I am sure that I will achieve my long-term savings goals; (3) At this point, I feel efficient.

Results. All the analyses were performed by the author. In order to verify the differences between groups, analysis of variance for independent samples and analysis of variance using the Bayes method were performed (Wagenmakers, Love, Marsman, et.al. forthcoming). Analysis of variance rejected the hypothesis of equality of means in groups $F(9,450)=3.03, p<0.01 ; \eta^{2}=0.06$, and Bayes analysis showed that the alternative hypothesis concerning differences is seven times more likely than the null hypothesis $\left(B F_{10}=7.19\right)$, indicating moderate strength of the effect (Lee and Wagenmakers 2013). The analysis of multiple comparisons showed that differences occurred only between the control group and the rest of the experimental groups (within them there were no significant differences $t<1, Z<1, B F_{01}>1.73$ ). The results are presented in the table 3 and figure 3 . In the case of mediation analysis, modelling of structural equations was used, which showed that self-efficacy did not mediate between motivators, intentions and variables of behaviour control and declaration of savings $(p>.411)$.

Summary. The results of the analysis confirmed hypothesis no. 3. It was proved that the temporary activation of motivation variables, intentions and behaviour control had an impact on saving. The participants under experimental conditions saved larger amounts in unexpected circumstances than those in the control group. The analysis of mediation did not confirm hypothesis no. 4. Contrary to predictions, it turned out that self-efficacy was not a psychological mechanism thanks to which people save more.

Table 3. Results of the experiments in study 2.

\begin{tabular}{|c|c|c|c|c|c|c|c|c|c|c|c|}
\hline Ref. & Group & $n$ & $M$ & $S D$ & s.e & $L C I$ & $U C I$ & $t$ & $z$ & Cohen's $d$ & $B F_{10}$ \\
\hline & CTRL & 44 & 42,16 & 36,41 & 4,50 & 33,32 & 51,00 & - & - & - & - \\
\hline & Risk awareness & 41 & 60,73 & 30,63 & 4,66 & 51,58 & 69,89 & $2,54 *$ & $2,51 *$ & 0,13 & 3,56 \\
\hline & Perceived benefits & 42 & 63,81 & 30,66 & 4,60 & 54,76 & 72,86 & $2,98 * *$ & $2,88 * *$ & 0,16 & 9,73 \\
\hline & Action self-efficacy & 38 & 64,61 & 24,14 & 4,84 & 55,09 & 74,12 & $3,23 * *$ & $3,01 * *$ & 0,16 & 18,60 \\
\hline \multirow{6}{*}{ CTRL } & Intention to saving & 56 & 69,43 & 26,42 & 3,99 & 61,59 & 77,26 & $4,34 * * *$ & $3,84 * * *$ & 0,21 & 561,03 \\
\hline & Monitoring & 55 & 65,16 & 30,27 & 4,02 & 57,26 & 73,07 & $3,43 * *$ & $3,18 * *$ & 0,18 & 33,04 \\
\hline & Action planning & 47 & 64,60 & 27,30 & 4,35 & 56,04 & 73,15 & $3,34 * *$ & $3,13 * *$ & 0,17 & 25,11 \\
\hline & Coping planning & 45 & 61,22 & 29,20 & 4,45 & 52,48 & 69,96 & $2,73 * *$ & $2,84 * *$ & 0,14 & 5,41 \\
\hline & Maintenance self-efficacy & 45 & 63,11 & 32,76 & 4,45 & 54,37 & 71,85 & $2,86^{* *}$ & $2,72 * *$ & 0,15 & 7,28 \\
\hline & Recovery self-efficacy & 47 & 69,57 & 29,11 & 4,35 & 61,02 & 78,13 & $3,98 * * *$ & $3,66 * * *$ & 0,20 & 163,88 \\
\hline
\end{tabular}




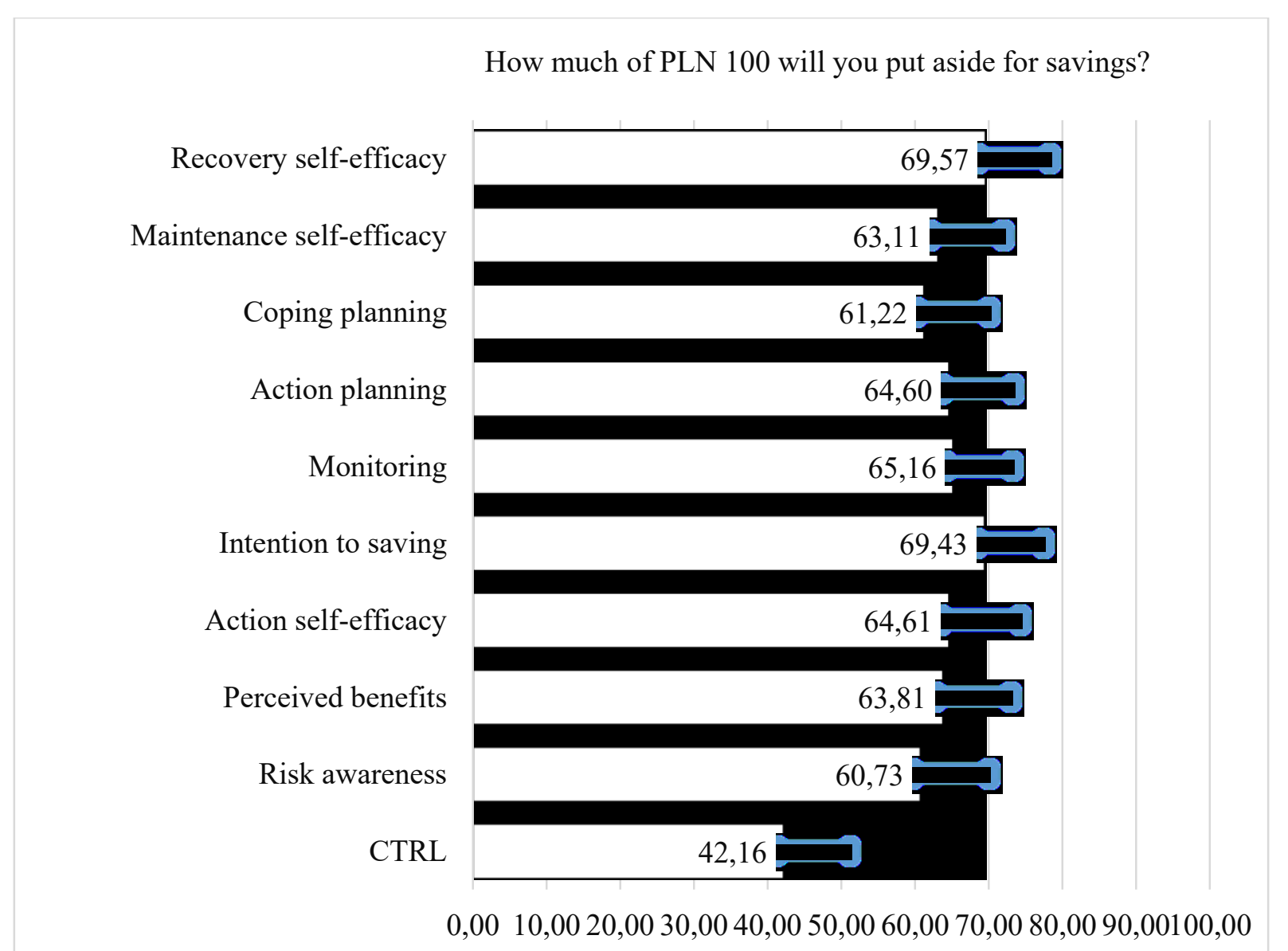

Figure 3. Results of the experiment.

Study 3 was a cognitive training aimed at working with motivational variables, intention and behaviour control to increase the level of savings. With the help of Facebook ads, people who have problems with spending money and want to learn to save were recruited for the training. Study 3 was a cognitive training programme aimed at working with motivational variables, intention and behaviour control to increase the level of savings. Of the 63 people who clicked on the training link, 13 volunteers left their contact data. Then 6 women who gave substantive reasons for saving were contacted. When asked, "why do you want to participate in the training?" they answered: (A.M.) "I would like to learn how to save effectively, so that I always have a certain amount of money for a socalled rainy day or vacation etc."; (K.M.) "I would like to learn how to save effectively, so that I always have a certain amount of money for a so-called rainy day or vacation etc."; (K.Z) "I do not set money aside. I spend as much as I earn."; (N.G.) "I would like to take part in the program because I have a problem with saving money, and this change could help me to become independent from my family, which is something I recently started to care about. I am in a difficult situation of retraining, because the humanities studies I had chosen and my previous habits make it impossible for me to achieve my goal and earn my living"; (O.S.) "I need to learn to save, all the advice on online forums is funny"; (G.A) "Because I currently experience financial problems. I think that they may be the result of my financial carelessness in the past when I was doing well. I hope to get out of this collapse and avoid mistakes like that in the future.". Four people declared moderate earnings and two indicated financial difficulties. Their age was $M=32.14, S D=10.11$ (range 20-56). One hypothesis was put forward in this study:

H5: Cognitive training will have an impact on the increase of the level of motivation, behaviour control as well as savings and a decrease in expenses.

Method: Training lasting on average 4.5 hours (with 15 min intervals every 1.5 hours) was given by the author of the article using the cognitive tasks described in the method of study 2. 
In each task, participants had to voice their opinions on the benefits and risks, as well as identify problems that prevent saving, making saving plans and elements to monitor their own behaviour and the everyday consumer environment in which they operate. The work was carried out on the basis of Socratic dialogue used in cognitivebehavioural therapy (Popiel and Pragłowska 2008). It consisted of asking questions and conducting conversations with participants in a way that allows them to think independently when working on assignments. The exception to the series of exercises from research 2 was the task of training for effectiveness maintenance. Participants in the training had to describe 10 situations in which it is difficult to save, but they manage to do it and assess what difficulty they cause, how much effort they have to put in to overcoming them and how they can cope with them. All training tasks are included in appendix B. The day before the test (pre-test) participants filled out the questionnaire used in study 1, and were also asked to declare how much money they managed to save, earn and spend in the previous month and also how high their cash bonuses (bonuses at work, cash presents or found money) were. An analogous survey was conducted 30 and 60 days after training (post-test). Only one person could not take part in the third measurement due to unforeseen reasons. The participants wrote down all their beliefs, actions and plans on the previously prepared training sheet (appendix B).

Results. The analysis was performed by the author. In order to verify the results of the training, two series of linear regression analyses were carried out. The first was an analysis of the random effects of constant intercepts and constant slopes of the regression line, and the second was a model of random intercepts and slopes of the regression line. These methods are presented by controlling the individual variation between subjects in terms of the exacerbation of measurements and training effects. In the tested models, the independent variables were three measurement deadlines (pre-test and post-test after 30 and 60 days), and dependent variables such as individual measurements of motivational and volitional variables, as well as earnings, expenses, savings, income (earnings + allowances) and revenue (income-expenses). The analysis showed that the training had no influence $(p>.10)$ on the level of earnings, allowances, income, risk awareness, perception of benefits, intentions and self-efficacy of recovery. The training was found to influence only borderline $(p<.10)$ the decrease in expenditure, income growth, action self-efficacy, monitoring and maintaining self-efficacy. A significant impact $(p<.05)$ was obtained in the case of planning and planning for coping, as well as savings expressed in PLN and the scale of a saving lifestyle. The results of the analysis are presented in table 4.

Summary. The adjustment values of regression models in terms of AIC coefficients with such a low number of respondents did not resolve the issue of inter-individual differences in terms of training effects. Nevertheless, both models returned convergent results. The analysis showed the direction of influence predicted in the hypothesis no. 5. The training had a beneficial effect on the saving behaviours held and assessed, as well as reduced expenses and raised the level of volitional variables. The training did not significantly affect earnings, income and cash supplements. This shows that they were at a constant level while tracking effects and can be excluded as factors affecting increased savings. The analysis also showed no changes in the context of awareness of risks, perceived benefits and intentions. This is an explanatory result due to the fact that the training participants were in the motivational attitude and the results of these measurements were very high at the beginning. Apparently, they benefited most from the training in terms strengthening their skills of monitoring, planning, planning for coping, action and maintaining self-efficacy. The exception is the observed lack of change in the measurement of recovery of effectiveness. Perhaps 60 days is too short a time for people to fail and test their skills in returning to saving. Although the results seem to be in line with expectations, they are not devoid of risk of erroneous conclusions. Due to the lack of a control group, the impact of training on the level of savings cannot be assessed. For the same reason, it cannot be ruled out that the measurement results were a consequence of the natural variability resulting from the duration of life or strength of intent itself.

Table 4. The results of the saving training.

\begin{tabular}{|c|c|c|c|c|c|c|c|c|c|}
\hline \multirow{2}{*}{ Measure } & \multirow{2}{*}{$\alpha$} & \multicolumn{4}{|c|}{ Random intercepts, fixed slopes } & \multicolumn{4}{|c|}{ Random intercepts and slopes } \\
\hline & & AIC & $\beta$ & $S E$ & $t$ & AIC & $\beta$ & $S E$ & $t$ \\
\hline Savings & - & 242,87 & 457,33 & 123,11 & $3,71 * *$ & 229,29 & 597,5 & 224,83 & $2,66^{*}$ \\
\hline Earnings & - & 266,47 & 487,22 & 371,02 & 1,31 & 279,60 & 460,21 & 379,25 & 1,21 \\
\hline Financial benefits & - & 236,07 & $-155,48$ & 144,99 & 1,07 & 234,98 & ${ }^{-}$ & 187,02 & 1,03 \\
\hline Expenditures & - & 249,62 & $-366,39$ & 173,04 & $2,12 \dagger$ & 252,89 & $\begin{array}{c}- \\
390,46\end{array}$ & 182,12 & $2,14 \dagger$ \\
\hline
\end{tabular}




\begin{tabular}{|c|c|c|c|c|c|c|c|c|c|}
\hline Revenue & - & 276,47 & 152,81 & 468,57 & 0,33 & 281,03 & 294,08 & 519,09 & 0,57 \\
\hline Income & - & 279,90 & 608,33 & 306,40 & $1,99 \dagger$ & 283,43 & 608,33 & 290,99 & $2,09 \dagger$ \\
\hline Risk awareness & 0,84 & 81,23 & $-0,15$ & 0,65 & $-0,24$ & 79,51 & 0,09 & 0,83 & 0,11 \\
\hline Perceived benefits & 0,80 & 88,13 & 0,27 & 0,90 & 0,30 & 82,95 & 0,37 & 1,22 & 0,31 \\
\hline Intention to saving & 0,82 & 66,73 & $-0,41$ & 0,43 & $-0,94$ & 57,69 & $-0,33$ & 0,56 & $-0,58$ \\
\hline Action self-efficacy & 0,91 & 81,14 & 2,43 & 0,71 & $3,42 * *$ & 80,03 & 2,26 & 0,96 & $2,35 \dagger$ \\
\hline Recovery self-efficacy & 0,80 & 78,67 & 0,82 & 0,68 & 1,19 & 81,72 & 0,77 & 0,73 & 1,07 \\
\hline Maintenance self-efficacy & 0,75 & 80,27 & 1,21 & 0,59 & $2,06 \dagger$ & 85,06 & 1,32 & 0,59 & $2,24 \dagger$ \\
\hline Monitoring & 0,93 & 99,95 & 2,65 & 1,28 & $2,07 \dagger$ & 106,31 & 2,5 & 1,31 & $1,91 \dagger$ \\
\hline Coping planning & 0,91 & 86,30 & 2,62 & 0,79 & $3,31 * *$ & 87,40 & 2,57 & 0,85 & $3,04 *$ \\
\hline Action planning & 0,94 & 88,28 & 3,17 & 0,85 & $3,72 * *$ & 89,98 & 3,18 & 0,91 & $3,49 * *$ \\
\hline \multirow[t]{2}{*}{ Saving life style } & 0,72 & 81,92 & 2,84 & 0,76 & $3,73 * *$ & 85,59 & 2,83 & 0,75 & $3,76^{* *}$ \\
\hline & & & & & & \multicolumn{4}{|c|}{$\dagger<0,10, * \mathrm{p}<.05, * * \mathrm{p}<.01, * * * \mathrm{p}<.001$} \\
\hline
\end{tabular}

6

\section{General discussion}

In this research, the accuracy of predictions in the context of a saving lifestyle was demonstrated. It has been shown that the intention to save is influenced by the benefits resulting from savings and the belief in the success of an individual's own actions towards savings. Due to the fact that only medical students financially supported by their parents were tested, the perception of threat and risks as a factor encouraging them to save was not observed. Although in the experiment in which this variable was manipulated, a higher level of savings was obtained in comparison with the control group. The mediation effect between intent and saving turned out to be significant and consistent with the theoretical predictions. The action control variables provided the intention to be implemented for the saving activity. This supports the hypothesis that behavioural control is critical in taking the intention to action (Kuhl 1984; Dholakia, Tam, Yoon and Wong 2016; Schwarzer 2008; Baumeister 2002; Baumeister and Vohs 2007). The experiment showed that the cognitive work associated with individual motivational and volitional elements affects putting aside of a higher amount of money. However, it was not observed that the sense of effectiveness was a mechanism mediating this relationship. It is possible that the activation of the idea of money per se mobilises the respondents to set aside larger sums as a way of being more independent of others (Vohs, Mead and Goode 2006). It is also possible that this relationship involves a sense of responsibility that is associated with the desire to allocate larger sums when creating reserves (Abigail and Rourke 2016) or a simple ease of performing a behaviour (Ajzen and Fishbein 1980; Fishbein and Ajzen 1975). Examination of this mechanism is necessary to explain the existence of this influence. However, training on savings turned out to be important for the participants. Those who participated in a $4.5 \mathrm{~h}$ training did so voluntarily. Based on the predictions resulting from the stages of behavioural change, it can be presumed the participation was motivated by the awareness of risks, benefits of saving and the faith in the possibility of achieving them. Therefore there were no changes on the level of these variables (Schwarzer 2008). What they wanted to achieve was simply learning to transform the will to save into a real behaviour. During the two months, the training participants declared similar earnings, lower expenses, as well as greater savings and increasing volitional variables. There is no change in the measure of recovery of self-efficacy. Apparently, the duration of studying the effects of the training was too short to allow them to observe difficulties and practice the ability of returning to saving after a failure. It is worth emphasising that a frequently cited article about saving is the report by Thaler and Benartzi (2004). Their impressive results relate to the use of a saving program implemented in companies called Smart Plan ${ }^{\mathrm{TM}}$, which increased the savings of its participants from $3.5 \%$ to $13.6 \%$ in 40 months. The respondents enrolled in a program in which their money was automatically and progressively deducted and added to their plan. This 
method was well managed with limited rationality in decision making, lack of behavioural self-control, procrastination and aversion to money losses and regret. The decision-making trick used by the authors is, from the economic point of view, a cheap and easy form of implementing and returning clear saving results. Nevertheless, from a psychological perspective, it has no impact on the change, that is, the development of personal saving abilities. The above series of studies indicates that we can influence people's attitudes and teach them skills that can help them achieve goals related to saving. Practitioners and legislators can use the results of this research for the purpose of social work with people and families with low incomes. People with low income can also adopt a different way of achieving consumer goals rather than seeking high-interest loans, and also spread the idea of a financially healthy lifestyle.

Limitations of research and recommendation

The series of studies in this research was conducted using volunteers. This can significantly reduce the external validity of the study, especially in the case of self-control training. The key to the unambiguous determination of changes caused by saving training is to perform an experiment with a randomised set of people assigned to the control and experimental groups, while extending the time of tracking the results of the intervention. This is necessary from the perspective of accurate control of the appearance of changes in the process of acquiring new financial skills and the level of savings. Future research in this field should seek answers about individual differences regarding the ease of motivating and achieving the goal of saving. A promising concept in this context is the verification of the dimension of the orientation towards state and action. Theoretical premises regarding greater ease of behavioural control in action-oriented people may provide a different form of motivation and implementation of saving behaviours than for state-oriented persons (Kuhl 1984, 1982; Kuhl and Geiger 1986). The aforementioned search for mediators between the activation of beliefs, behaviours and action plans, and real saving, is important from the perspective of practical work with people in need of support. Effective action in this area requires knowledge of mechanisms that support the consumer in his or her beneficial behaviours. Equally important seems to be using behavioural measures of saving actions and testing successive motivational and volitional variables to be able to maximise the variability of intent and behaviour. By discovering new psychological mechanisms, it will be possible to formulate a reliable model with high predictive properties and simplicity in explaining the saving of money and promoting a saving lifestyle.

\section{References:}

Abigail B. Sussman and Rourke L. O’Brien (2016). Knowing When to Spend: Unintended Financial Consequences of Earmarking to Encourage Savings. Journal of Marketing Research. Vol. 53, No. 5, pp. 790-803.

Ajzen, I., and Fishbein, M. (1980). Understanding attitudes and predicting social behavior. Englewood Cliffs, N.J.: Prentice Hall.

Ajzen, I. (1985). From Intentions to Actions: A Theory of Planned Behavior. Action Control, 11-39.

Bagozzi, R. P., and Warshaw, P. R. (1990). Trying to Consume, 17(September).

Bandura, A. (1977). Self-efficacy: Toward a unifying theory of behavioral change. Psychological Review, 84, 191-215.

Bandura, A. (1997). Self-efficacy: The exercise of control. New York: Freeman.

Bandura, A., and Adams, N. E. (1977). Analysis of self-efficacy theory of behavioral change. Cognitive Therapy and Research, 1(4), 287-310.

Baron, R. M., and Kenny, D. A. (1986). The moderator-mediator variable distinction in social psychological research: Conceptual, strategic and statistical considerations. Journal of Personality and Social Psychology, 51, 1173-1182.

Baumeister, R. F. (2002). Yielding to temptation: Self- control failure, impulsive purchasing, and consumer behavior. Journal of Consumer Research, 28, 670-676.

Baumeister, R. F., and Vohs, K. D. (2007). Self-Regulation, Ego Depletion, and Motivation. Social and Personality Psychology Compass, 1(1), 115-128.

Delgadillo, L. M. (2014). Financial Clarity: Education, literacy, capability, counseling, planning, and coaching. Family and Consumer Sciences Research Journal, 43(1), 18- 28.

Dholakia, U., Tam, L., Yoon, S., and Wong, N. (2016). The ant and the grasshopper: Understanding personal saving orientation of consumers. Journal of Consumer Research, 43(1), 134-155.

Drever, A. I., Odders-White, E., Kalish, C. W., Else-Quest, N. M., Hoagland, E. M., and $\quad$ Nelms, E. N. (2015). Foundations of financial well-being: Insights into the role of executive function, financial socialization, and experience-based learning in childhood and youth. Journal of Consumer Affairs, 49(1), 13-38.

Faber, R. J., and Vohs, K. D. (2011). Self-regulation and spending: Evidence from impulsive and compulsive buying. Handbook of Self-Regulation: Research, Theory, and Applications, 537-550. 
Fishbein, M., and Ajzen, I. (1975). Belief, attitude, intention, and behavior: An introduction research. Reading, MA: Addison-Wesley.

Garbinsky, E. N. (2013). How Thinking About Money Changes Goal Pursuit. Advances in Research, 41(66), 105-109.

Gollwitzer, P.M. (1999). Implementation intentions: Strong effects of simple plans. American 54, 493-503.

Gollwitzer, P.M., and Sheeran, P. (2006). Implementation intentions and goal achievement: A of effects and processes. Advances in Experimental Social Psychology, 38, 69-119.

Goschke, T., and Kuhl, J. (1993). Representation of intentions: Persisting activation in memory. Journal of Experimental Psychology: Learning, Memory, and Cognition, 19(5), 1211-1226.

Jian, J., Chen, C., and Chen, F. (2014). Consumer financial capability and financial satisfaction. Social Indicators Research, 118(1), 415-432.

Kuhl, J. (1983). Emotion, Kognition und Motivation : II. Die funktionale Bedeutung der und Kognition, 4. 228-253.

Kuhl, J. (1984). Volitional aspects of achievement motivation and learned helplessness: Toward comprehensive theory of action control. In B.A. Maher (Ed.), Progress in Personality Research (Vol.13). (pp.99-171). New York: Academic

Press.

Experimental

Kuhl, J. (2000). A functional-design approach to motivation and self-regulation: The dynamics of personality systems and interactions. In M. Boekaerts, P. R. Pintrich, \& $\quad$ M. Zeidner (Ed.), Handbook of selfregulation (pp. 111-169). San Diego, CA, US: Academic Press

Kuhl, J., and Helle, P. (1986). Motivational and volitional determinants of depression: The intention hypothesis. Journal of Abnormal Psychology, 95, 247-251.

Kuhl, J., Geiger, E. (1986). The dynamic theory of the anxiety-behavior relationship: A study of resistance and time allocation, In J. Kuhl, J. W. Atkinson (Ed.), Motivation, thought, and action (pp. 76-93). New York: Praeger.

Lee, M. D., and Wagenmakers, E.-J. (2013). Bayesian cognitive modeling: A practical course. Cambridge University Press.

Leventhal, H., Rabin, C., Leventhal, E.A., and Burns, E. (2001). Health risk behaviors and aging. In J.E. Birren and K.W. Schaie (Ed.), Handbook of the psychology of aging (5th edn., pp. 186-214). San Diego, CA: Academic Press.

Leventhal, H., Safer. M. A., and Panagis, D. M. (1983). The impact of communications on the self-regulation of health beliefs, decisions, and behavior. Health Education Quarterly, 10, 3-29.

Marlatt, G.A. (2002). Harm reduction: Pragmatic strategies for managing high-risk behaviors. New York: Guilford.

Marlatt, G.A., Baer, J.S., and Quigley, L.A. (1995). Self-efficacy and addictive behavior. In A. Bandura (Ed.), Self-efficacy in changing societies (pp. 289-315). New York:

Cambridge University Press.

O'Guinn, T. C., and Faber, R. J. (1989). Compulsive buying: A phenomenological exploration. Journal of Consumer Research, 16, 147-157.

Popiel, A., Pragłowska, E.(2008). Psychoterapia poznawczo-behawioralna. Teoria i praktyka. Warszawa: Wydawnictwo Paradygmat. s.145.

Prochaska, J. O., Wright, J. A., and Velicer, W. F. (2008). Evaluating theories of health behavior change: hierarchy of criteria applied to the transtheoretical model. Applied Psychology, 57(4), 561-588.

Renner, B. (2003). Hindsight bias after receiving self-relevant health risk information: A motivational perspective. Memory, 11(4-5), 455-472.

Rook, D. W., and Fisher, R. J. (1995). Normative influences on impulsive buying behavior. Journal of Consumer Research, 22, 305-313.

Rook, D. W., and Gardner, M. P. (1993). In the mood: Impulse buying's affective Research in Consumer Behavior, 6, 1-28.

Scholz, U., Sniehotta, F.F., and Schwarzer, R. (2005). Predicting physical exercise in cardiac rehabilitation: The role of phase-specific self-efficacy beliefs. Journal of Sport and Exercise Psychology, 27, 135151.

Schüz, B., Sniehotta, F.F., and Schwarzer, R. (2007). Stage-specific effects of an action control intervention on dental flossing. Health Education Research, 22, 332-341.

Schwarzer, R. (2008) Modeling Health Behavior Change: How to Predict and Modify the Adoption and Maintenance of Health Behaviors. Applied Psychology: An International Review, 57, 1-29.

Sotiropoulos, V., and d'Astous, A. (2013). Attitudinal, Self-Efficacy, and Social Norms Determinants of Young Consumers' Propensity to Overspend on Credit Cards. Journal of Consumer Policy, 36(2), 179-196.

Steinmetz, H., Knappstein, M., Ajzen, I., Schmidt, P., and Kabst, R. (2016). How Effective are Behavior Change Interventions Based on the Theory of Planned Behavior? Zeitschrift Für Psychologie, 224(3), 216-233. 
Taylor, M. P., Jenkins, S. P., and Sacker, A. (2011). Financial capability and psychological of Economic Psychology, 32(5), 710-723.

Thaler, Richard H., and Shlomo Benartzi. 2004. Save more tomorrow: Using behavioral increase employee saving. Journal of Political Economy 112(S1): S164- S187.

Vohs, K. D., Mead, N. L., and Goode, M. R. (2006). The psychological consequences of Science, 314(5802), 1154-1156.

von Stumm, S., Fenton O'Creevy, M., and Furnham, A. (2013). Financial capability, money socioeconomic status: Risks for experiencing adverse financial events. Personality Differences, 54(3), 344-349.

Vroom, V. H. (1964). Work and motivation. New York: John Wiley and Sons.

Wagenmakers, E.-J., Love, J., Marsman, M., Jamil, T., Ly, A., Verhagen, A. J., Selker, R., ～Gronau, Q. F., Dropmann, D., Boutin, B., Meerhoff, F., Knight, P., Raj, A., van $\quad$ Kesteren, E.-J., van Doorn, J., Smira, M., Epskamp, S., Etz, A., Matzke, D., de Jong, T., van den Bergh, D., Sarafoglou, A., Steingroever, H., Derks, K., Rouder, J. N., and Morey, R. D. (in press). Bayesian inference for psychology. Part II: Example applications with JASP. Psychonomic Bulletin and Review.

Worthy, S. L., Jonkman, J., and Blinn-Pike, L. (2010). Sensation-Seeking, Risk-Taking, and Problematic Financial Behaviors of College Students. Journal of Family and Economic Issues, 31(2), 161-170.

Zeigarnik, B. (1927). Das Behalten erledigter und unerledigter Handlungen. Psychologische Forschung, 9 , $1-85$.

\section{Appendix A}

\begin{tabular}{|c|c|}
\hline Factor & Item \\
\hline \multirow{3}{*}{ Risk Awareness } & Compared to the average person of my sex and age, the chances that I can struggle to make ends meet are high \\
\hline & Compared to the average person of my sex and age, the chances that I can go bankrupt in life are high \\
\hline & Compared to the average person of my sex and age, the chances of me suffering from lack of money are high \\
\hline \multirow{7}{*}{ Perceived benefits } & What are your personal benefits of saving? If I save: \\
\hline & I have more money \\
\hline & I can make ends meet \\
\hline & I have more savings \\
\hline & I can buy something I dreamed about \\
\hline & I put some money away for a rainy day \\
\hline & I'm calmer \\
\hline \multirow{5}{*}{$\begin{array}{l}\text { Action Self- } \\
\text { efficacy }\end{array}$} & Different barriers make it hard to save. How confident / sure are you to start doing it? I'm sure that: \\
\hline & Nothing can stop me from saving \\
\hline & I will always overcome problems appearing on the way to save some money \\
\hline & Even when it is difficult I will always put something aside \\
\hline & I can easily save something \\
\hline \multirow{6}{*}{$\begin{array}{l}\text { Maintenance Self- } \\
\text { efficacy }\end{array}$} & I am sure that I can resist the temptation of unplanned expenses and save: \\
\hline & Even when my budget is depleted \\
\hline & Even when I lose my source of income \\
\hline & Even when I'm on an accidental shopping trip with friends \\
\hline & Even when something changes in my life (day plan, new acquaintance, trip) \\
\hline & Even when I will in a positive or negative mood \\
\hline \multirow{2}{*}{$\begin{array}{l}\text { Recovery Self- } \\
\text { efficacy }\end{array}$} & $\begin{array}{l}\text { Imagine that you do not save money. How confident are you that you will return to the habit of saving? I am sure that } \\
\text { I will come back to saving again: }\end{array}$ \\
\hline & Even when I have a lot of money \\
\hline
\end{tabular}




\begin{tabular}{|c|c|}
\hline & Even when I will not have anything to save for \\
\hline & Even when I occasionally buy something that I did not plan \\
\hline & Even when I will not save for a period of time \\
\hline & Even when I come back to unplanned spending for some time \\
\hline \multirow{4}{*}{ Intention } & What are your intentions? \\
\hline & I'm going to save money \\
\hline & I'm going to have big savings \\
\hline & I want to create a reserve of money \\
\hline \multirow{7}{*}{ Action Planning } & $\begin{array}{l}\text { If you save or want to save something, do you have clear plans about when, where and how you will do it? I have } \\
\text { detailed plans for this: }\end{array}$ \\
\hline & How to plan the expenses to save something \\
\hline & How to organise your life to save something \\
\hline & I know when and how to plan expenses to save and live normally \\
\hline & I know when to save money \\
\hline & How to organise my life and expenses to save \\
\hline & I know in which situations I will be able to save \\
\hline \multirow{6}{*}{ Coping Planning } & $\begin{array}{l}\text { Do you have ideas on how to deal with any obstacles that could interfere with your goal of saving? I have a detailed } \\
\text { plan: }\end{array}$ \\
\hline & What to do when I am in a situation of unexpected expenses at the instigation of friends \\
\hline & How to act in the event of strong shopping temptations \\
\hline & How to avoid situations in which saving is difficult or impossible \\
\hline & How to avoid situations where money is spent without a plan (events, holidays, mood changes) \\
\hline & How to arrange my life routine to be able to save \\
\hline \multirow{8}{*}{ Monitoring } & Recently: \\
\hline & I was watching for when and where I could save something \\
\hline & I often had the intention to save something \\
\hline & I tried very hard to save something regularly \\
\hline & I can say that I watched for the opportunity to save money \\
\hline & I often thought about where and when I could save for something \\
\hline & I remember when and where I saved something \\
\hline & I monitored my environment in search of opportunities to save money \\
\hline \multirow{5}{*}{ Saving lifestyle } & I have big savings \\
\hline & I manage to create a financial reserve \\
\hline & My life is so organised that I live normally and save \\
\hline & I create savings to deal with future expenses \\
\hline & I conscientiously try to save \\
\hline
\end{tabular}

The scale of answers: Not true, A little untruth, Little truth, Truth.

\section{Appendix B.}


1. Risk awareness.

(6)

2. Perceived benefits.

(6)

3. Actions self-efficacy.

\begin{tabular}{c|l|l}
\hline & Problems that prevent you from saving? & How will you deal with them? \\
\hline$(6)$ & & \\
\hline
\end{tabular}

4. Intention to saving.

\begin{tabular}{c|c|c|c}
\hline & What do you want to save for? & $\begin{array}{c}\text { What is the } \\
\text { amount? }\end{array}$ & $\begin{array}{c}\text { How much time do you want } \\
\text { to do it in? }\end{array}$ \\
\hline$(5)$ & & & \\
\hline
\end{tabular}

5. Monitoring.

\begin{tabular}{l|l}
\hline & $(5)$ \\
\hline How do you know that you save? & \\
\hline In what everyday life situations can you save? & \\
\hline What can you do to create the opportunity to save? & \\
\hline How would you evaluate your saving? & \\
\hline
\end{tabular}

6. Regaining self-efficacy.

\begin{tabular}{c|c|c}
\hline & $\begin{array}{c}\text { Write what can prevent (something } \\
\text { that completely interrupts or conflicts } \\
\text { with your saving habit) you from } \\
\text { saving. }\end{array}$ & $\begin{array}{c}\text { What are you doing to go back to } \\
\text { saving? }\end{array}$ \\
\hline$(6)$ & & \\
\hline
\end{tabular}

7. Maintenance self-efficacy.

\begin{tabular}{c|c|c|c|l}
\hline & $\begin{array}{c}\text { What are the } \\
\text { situations? }\end{array}$ & $\begin{array}{c}\text { How difficult is it } \\
\text { for you? (1-10) }\end{array}$ & $\begin{array}{c}\text { How much effort do } \\
\text { you have to put into } \\
\text { overcoming it? (1-10) }\end{array}$ & $\begin{array}{l}\text { How long will you } \\
\text { struggle with this? } \\
(1-10)\end{array}$ \\
\hline$(10)$ & & & & \\
\hline
\end{tabular}

8. Action planning.

\begin{tabular}{c|c|c|c|c|}
\hline & $\begin{array}{c}\text { In which situations can } \\
\text { you save? }\end{array}$ & $\begin{array}{c}\text { When can you do } \\
\text { it? }\end{array}$ & $\begin{array}{c}\text { Where can you do } \\
\text { this? }\end{array}$ & How can you do it? \\
\hline$(6)$ & & & & \\
\hline
\end{tabular}

9. Coping planning. 


\begin{tabular}{c|c|c|c}
\hline & $\begin{array}{c}\text { What problems can } \\
\text { occur on the way to } \\
\text { saving? }\end{array}$ & $\begin{array}{c}\text { How can you stop them from } \\
\text { happening? }\end{array}$ & $\begin{array}{c}\text { What can you do to deal with them } \\
\text { when they occur? }\end{array}$ \\
\hline$(6)$ & & & \\
\hline
\end{tabular}

